\title{
A guide to the cost of progesterone for prevention of preterm labor
}

\author{
Joseph T. Kowalski, MD ${ }^{1}$ \\ Keywords: Progesterone, Preterm Labor, Health Care Costs
}

Progesterone, in various forms, has been the sole pharmacologic weapon against preterm labor supported by randomized controlled trials since the groundbreaking work of da Fonseca ${ }^{1}$ and Meis $^{2}$ in the early 2000s.

Progesterone is indicated in preventing recurrent preterm labor and preterm delivery in the setting of a history preterm delivery due to cervical insufficiency or unexplained preterm delivery. This is what the evidence supports. However, many investigators are trying to expand the indications for the use of progesterone. These include using progesterone in twin pregnancies and in the setting of a short cervix. To date, no investigator has published data supporting the use of of progesterone in multiple gestations. However, there is good evidence to support the use of progesterone in women with a short cervix.

${ }^{1}$ Department of Obstetrics and Gynecology, Carver College of Medicine, University of lowa Hospitals and Clinics, lowa City, IA
This was recently reaffirmed by work done by Hassan, et al as part of the PREGNANT trial. $^{3}$ Furthermore, a decision and cost analysis by Cahill, et al showed that universal screening for a short cervix and treatment with vaginal progesterone was cost effective. ${ }^{4}$ However, the most recent ACOG guidelines only support the use of progesterone in women with an incidentally found short cervix. ${ }^{5}$

Nightly vaginal suppositories and weekly injections were the first forms of progesterone proved to be effective in preventing preterm labor. The effectiveness of nightly vaginal gel was then demonstrated by O'Brien ${ }^{6}$. These options are all relatively affordable. Suppositories and gel are only available in branded forms under the names Endometrin, Crinone and Prochieve. Until recently the intramuscular injection form was only available from compounding pharmacies.

Please cite this paper as: Kowalski, JT. A Guide to the Cost of Progesterone for Prevention of Preterm Labor. Proc Obstet Gynecol. 2011 April;1(3):Article 9 [4 p.]. Available from: http://ir.uiowa.edu/pog/. Free full text article.

Corresponding author: Joseph Kowalski, Department of Obstetrics and Gynecology, University of lowa, 51244 PFP, 200 Hawkins Drive, lowa City, IA 42242. joseph-kowalski@uiowa.edu

This is an Open Access article distributed under the terms of the Creative Commons Attribution 3.0 Unported License (http://creativecommons.org/licenses/by/3.0), which permits unrestricted use, distribution, and reproduction in any medium, provided the original work is properly cited. 
K-V Pharmaceutical, through its wholly owned subsidiary, Ther-Rx Corporation, recently brought Makena to the market. This is an FDA-approved once weekly injection of 17-alpha-OH-progesterone caproate intended for the prevention of preterm labor. Although having this available in retail pharmacies would make prescribing progesterone for patients easier in some circumstances, the cost was widely felt to be prohibitively expensive for the vast majority of patients - $\$ 1500$ per injection. Therefore, the total retail price of prescribing Makena for weeks 16 through 36 in a pregnancy would be $\$ 31,500$. Makena was met with much resistance from the OBGYN community for this reason. The situation was particularly frightening because the manufacturer of Makena had sent cease and desist orders to compounding pharmacies that made progesterone injections. Thus, the only option for injectable progesterone would have been inaccessible to most patients due to cost.

After much lobbying from the American College of Obstetricians and Gynecologists (ACOG), the Society for Maternal-Fetal Medicine, and other societies, the FDA made an unprecedented statement on
March $30^{\text {th }}$ of this year. They announced that the FDA "does not intend to take enforcement action against pharmacies that compound hydroxyprogesterone caproate." $\mathrm{K}-\mathrm{V}$ Pharmaceutical announced on April $1^{\text {st }}$ that it would lower the price of Makena from $\$ 1500$ to $\$ 690$ per dose. Presumably, this was in response to the backlash that the company received from the OBGYN community, the FDA and the press. ${ }^{8}$ However, according to ACOG, this price reduction remains a "woefully inadequate response."

Fortunately, there are other forms of progesterone available, at very reasonable prices, for preterm labor prophylaxis. Table 1 is a guide to the various forms of progesterone currently available. The total cost is based on a 21-week course of treatment, starting at 16 weeks gestation and continuing until 36 completed weeks. Several factors must be considered when choosing a product for a patient. These include route of administration, patient preference, local availability and cost.

It is hoped that the information provided in this review will be helpful to practitioners who care for at risk women. 
Proceedings in Obstetrics and Gynecology, 2011 April; 1(3):9

Table 1: Various forms of progesterone and associated costs for 21-week course of treatment

\begin{tabular}{|l|l|l|l|l|}
\hline Formulation & Dosing & Retail price & Price per dose & $\begin{array}{l}\text { Total cost for 21 } \\
\text { weeks of } \\
\text { treatment }\end{array}$ \\
\hline Endometrin & $\begin{array}{l}100 \mathrm{mg} \text { vaginal } \\
\text { insert nightly }\end{array}$ & $\begin{array}{l}\text { \$157 per 21 } \\
\text { insert pack }\end{array}$ & $\$ 7.48$ & $\$ 1,099.56$ \\
\hline Prometrium & $\begin{array}{l}100 \mathrm{mg} \text { vaginal } \\
\text { capsule nightly }\end{array}$ & $\begin{array}{l}\$ 69 \text { per } 30 \\
\text { capsules }\end{array}$ & $\$ 2.30$ & $\$ 338.10$ \\
\hline Crinone & $\begin{array}{l}90 \mathrm{mg} \text { vaginal } \\
\text { gel nightly }\end{array}$ & $\begin{array}{l}\$ 170 \text { per } 10 \\
\text { tubes }\end{array}$ & $\$ 17.00$ & $\$ 2,499.00$ \\
\hline Prochieve & $\begin{array}{l}90 \mathrm{mg} \text { vaginal } \\
\text { gel nightly }\end{array}$ & $\begin{array}{l}\text { \$221 per } 18 \\
\text { tubes }\end{array}$ & $\$ 12.28$ & $\$ 1,805.16$ \\
\hline Makena & $\begin{array}{l}250 \mathrm{mg} \\
\text { intramuscular } \\
\text { weekly }\end{array}$ & $\begin{array}{l}\$ 690 \text { per } \\
\text { injection }\end{array}$ & $\$ 690.00$ & $\$ 14,490.00$ \\
\hline $\begin{array}{l}\text { Compounded 17- } \\
\text { alpha-OH- } \\
\text { progesterone } \\
\text { caproate* }\end{array}$ & $\begin{array}{l}250 \mathrm{mg} \\
\text { intramuscular } \\
\text { weekly }\end{array}$ & $\begin{array}{l}\$ 136 \text { per } 10 \\
\text { injections }\end{array}$ & $\$ 13.60$ & $\$ 285.60$ \\
\hline
\end{tabular}

Retail pricing according to www.drugstore.com

*Pricing from Wedgewood Pharmacy, Swedesboro, NJ, USA

References

1. da Fonseca EB, Bittar RE, Carvalho $\mathrm{MH}$, Zugaib $\mathrm{M}$. Prophylactic administration of progesterone by vaginal suppository to reduce the incidence of spontaneous preterm birth in women at increased risk: a randomized placebo-controlled double-blind study. Am J Obstet Gynecol. 2003 Feb;188(2):419-24.

2. Meis PJ, Klebanoff M, Thom E, Dombrowski MP, Sibai B, Moawad $\mathrm{AH}$, Spong CY, Hauth JC, Miodovnik M, Varner MW, Leveno KJ, Caritis SN, lams JD, Wapner RJ, Conway D, O'Sullivan MJ, Carpenter M, Mercer B, Ramin SM, Thorp JM, Peaceman AM, Gabbe S; National Institute of Child Health and Human Development MaternalFetal Medicine Units Network. Prevention of recurrent preterm delivery by 17 alphahydroxyprogesterone caproate. N Engl J Med. 2003 Jun 12;348(24):2379-85. Erratum in: N Engl J Med. 2003 Sep 25;349(13):1299.

Progesterone for Prevention of Preterm Labor
3. Hassan SS, Romero R, Vidyadhari D, Fusey S, Baxter J, Khandelwal M, Vijayaraghavan $\mathrm{J}$, Trivedi Y, Soma-Pillay P, Sambarey P, Dayal A, Potapov V, O'Brien J, Astakhov V, Yuzko O, Kinzler W, Dattel B, Sehdev H, Mazheika L Manchulenko D, Gervasi MT, Sullivan L, Conde-Agudelo A, Phillips JA, Creasy GW; for the PREGNANT Trial. Vaginal progesterone reduces the rate of preterm birth in women with a sonographic short cervix: a multicenter, randomized, doubleblind, placebo-controlled trial. Ultrasound Obstet Gynecol. 2011 Apr 6. [Epub ahead of print].

4. Cahill AG, Odibo AO, Caughey $A B$, Stamilio DM, Hassan SS, Macones GA, Romero R. Universal cervical length screening and treatment with vaginal progesterone to prevent preterm birth: a decision and economic analysis. Am J Obstet Gynecol. 2010 Jun;202(6):548.e1-8. Epub 2010 Jan 15. 
5. Society for Maternal Fetal Medicine Publications Committee. ACOG Committee Opinion number 419 October 2008 (replaces no. 291, November 2003). Use of progesterone to reduce preterm birth. Obstet Gynecol. 2008 Oct;112(4):963-5.

6. O'Brien JM, Adair CD, Lewis DF, Hall DR, Defranco EA, Fusey S, Soma-Pillay $\mathrm{P}$, Porter $\mathrm{K}$, How $\mathrm{H}$, Schackis R, Eller D, Trivedi $Y$, Vanburen G, Khandelwal M, Trofatter K, Vidyadhari D, Vijayaraghavan J, Weeks J, Dattel B, Newton E, Chazotte C, Valenzuela G, Calda P, Bsharat M, Creasy GW. Progesterone vaginal gel for the reduction of recurrent preterm birth: primary results from a randomized, double-blind, placebocontrolled trial. Ultrasound Obstet Gynecol. 2007 Oct;30(5):687-96.

7. U.S. Food and Drug Administration. FDA Statement on Makena. http://www.fda.gov/NewsEvents/Ne wsroom/PressAnnouncements/ucm 249025.htm. March 30, 2011. Accessed April 4, 2011.

8. Associated Press. Preemie birth preventive spikes from $\$ 10$ to $\$ 1,500$.

http://www.google.com/hostednews/ ap/article/ALeqM5jCfX0J7bSvYIQ n Q29gl1XqJEl A?docld=3ed07e159 62b4fbaad9a916d7fc3e249. March 9, 2011. Accessed April 4, 2011.

9. American College of Obstetricians and Gynecologists. Makena ${ }^{\mathrm{TM}}$ Price Reduction Is Inadequate: Medical and Clinician Groups Say Price Remains Prohibitive. Apr 12011. http://www.acog.org/from home/pub lications/press releases/nr04-0111.cfm. April 1, 2011. Accessed April 4, 2011. 